\title{
EXPRESSÃO DO FATOR DE CRESCIMENTO ENDOTELIAL VASCULAR (VEGF) E SEUS RECEPTORES VEGFR-1 E VEGFR-2 DURANTE O INÍCIO DA GESTAÇÃO EM CAMUNDONGOS
}

Dissertação apresentada ao Programa de Pós-Graduação em Biologia Celular e Tecidual do Instituto de Ciências Biomédicas da Universidade de São Paulo, para obtenção do Título de Mestre em Ciências. 


\title{
EXPRESSÃO DO FATOR DE CRESCIMENTO ENDOTELIAL VASCULAR (VEGF) E SEUS RECEPTORES VEGFR-1 E VEGFR-2 DURANTE O INÍCIO DA GESTAÇÃO EM CAMUNDONGOS
}

\author{
Dissertação apresentada ao Programa de \\ Pós-Graduação em Biologia Celular e \\ Tecidual do Instituto de Ciências Biomédicas \\ da Universidade de São Paulo, para obtenção \\ do Título de Mestre em Ciências. \\ Área de concentração: \\ Biologia Celular e Tecidual \\ Orientador: \\ Prof. Dr. Sérgio Ferreira de Oliveira
}




\section{RESUMO}

Silva LO. Expressão do Fator de Crescimento Endotelial Vascular (VEGFA) e seus receptores VEGFR-1 e VEGFR-2 durante o início da gestação em camundongos [tese]. São Paulo: Instituto de Ciências Biomédicas, Universidade de São Paulo; 2008.

Em roedores, o aumento da permeabilidade vascular, a transformação decidual, e angiogênese são eventos cruciais para o sucesso da gestação. $O$ fator endotelial vascular (VEGF) é um mitogênico para células endoteliais e um indutor de angiogênese. O VEGF age via dois receptores da família das tirosinas quinases: VEGFR-1(Flt-1) e VEGFR-2 (KDR/Flk-1). Embora as células endoteliais sejam o principal alvo do VEGF, em células não endoteliais, o VEGF e seus receptores têm demonstrado exercer um efeito funcional sobre a proliferação e diferenciação celular. O objetivo deste estudo foi investigar usando o método imunohistoquímico, a expressão espacial e temporal do VEGF e seus receptores VEGFR-1 e VEGFR-2, em células endometriais de camundongo entre o $4^{\circ}$ e $8^{\circ}$ dias de gestação. No $4^{\circ}$ dia de gestação, VEGF, VEGFR-1 e VEGFR-2 foram expressos pelo epitélio luminal e glandular. Células do estroma endometrial e o miométrio mostram uma marcação muito fraca. Do $5^{\circ}$ ao $8^{\circ}$ dias de gestação, o VEGFR-1 foi expresso pelas células do epitélio luminal e glandular e mostrou um aumento e uma marcação uniforme por toda a decídua mesometrial e antimesometrial. O receptor VEGFR-1 foi altamente expresso pelas células endoteliais dos capilares sinusóides mesometriais. A expressão de VEGFR-2 nos tecidos uterinos mostrou o mesmo padrão de marcação que aquele do VEGFR-1, exceto pela diminuição de marcação nas células da decídua madura antimesometriais. $\mathrm{O}$ receptor VEGFR-2 mostrou uma intensa marcação nas células pré-deciduais mesometriais e antimesometriais. O receptor VEGFR-2 foi altamente expresso pelas células endoteliais dos capilares sinusóides mesometriais. Em contraste com o endométrio decidualizado, a marcação para VEGF, VEGFR-1 e VEGFR-2 foi negativa no estroma endometrial dos sítios de inter-implantação. No $7^{\circ}$ e $8^{\circ}$ dias de gestação, a marcação para o VEGF, VEGFR1 e VEGFR-1 e os seus receptores foi intensa nas células Nk uterinas. VEGF, VEGFR-1 e VEGFR-2 foram diferencialmente expressos pelas células trofoblásticas gigantes e pelas células do cone ectoplacentário sugerindo que o VEGF possa está envolvido na invasão e diferenciação do trofoblasto. Estes resultados confirmam observações prévias que indicam 
que o aumento da expressão de VEGF, VEGFR-1 e VEGFR-2 pelas células deciduais e células em processo de decidualização possam estar relacionado a um aumento de permeabilidade que ocorre durante a implantação e decidualização. Os resultados também sugerem que durante a decidualização, além das funções angiogênicas, O VEGF e os seus receptores possam está envolvidos em outros processos celulares tais como, proliferação, sobrevivência e/ou diferenciação da célula decidual.

Palavras Chaves: VEGF; VEGFR-1; VEGFR-2; Imunohistoquímica; Endométrio; Decídua; Angiogênese; Implantação embrionária. 


\begin{abstract}
Silva LO. Expression of vascular endothelial growth factor (VEGF) and its receptors VEGFR-1 and VEGFR-2 during early pregnancy in mice [thesis]. São Paulo: Instituto de Ciências Biomédicas, Universidade de São Paulo; 2008.

In rodents, increase of vascular permeability, decidual cell transformation, and uterine angiogenesis are crucial events for the success of pregnancy. Vascular endothelial growth factor (VEGF) is a mitogen for endothelial cells and an inducer of angiogenesis. VEGF acts via two tyrosine kinase family receptors: VEGFR-1(Flt-1) and VEGFR-2(KDR/Flk-1). Although endothelial cells are the main target of VEGF, in some nonendotehlial cells VEGF and its receptors have shown functional effects on cell proliferation and differentiation. The aim of this study was to investigate using the immunohistochemical method, the spatiotemporal expression of VEGF and its receptors VEGFR-1 e VEGFR-2 by mouse endometrial cells on days 4 to 8 of pregnancy. On day 4, VEGF, VEGFR-1 and VEGFR-2 were expressed mostly by the luminal and glandular epithelium. Stromal cells and the myometrium showed a very weak labeling. On days 5-8, VEGF and its receptors showed an increased and uniform labeling throughout the mesometrial and antimesometrial decidua. The expression of VEGF, VEGFR-1, and VEGFR-2 was differentially expressed in the mesometrial cells and in the predecidual cells of the antimesometrial decidua. On days 5-8, VEGFR-1 was expressed by the luminal and glandular epithelium, and showed an increased and uniform labeling throughout the antimesometrial and mesometrial decidua. The receptor VEGFR-1 was highly expressed by endothelial cells of the mesometrial sinusoids. The expression of VEGFR-2 in the uterine tissues followed the same pattern of that from VEGF-R1, excepting by the decrease of labeling on antimesometrial mature decidual cells. The receptor VEGFR-2 showed a highly positive staining in the antimesometrial and mesometrial predecidual cells. The receptor VEGFR-2 was also highly expressed by endothelial cells of the mesometrial sinusoids. In contrast, endometrial stromal cells from interimplantation sites were negative for VEGF, VEGFR-1, and VEGFR-2. The expression of VEGF, VEGFR-1, and VEGFR-2 were intense in the uterine NK cells during days 7 and 8 of pregnancy. VEGF, VEGFR-1, and VEGFR-2 was differentially expressed by trophoblast giant cells and cells of the ectoplacental cone
\end{abstract}


suggesting that VEGF may be involved in trophoblast invasion and differentiation. These results confirm previous observations indicating that the increased expression of VEGF, VEGFR-1, and VEGFR-2 by decidual cells and cells in processs of decidualization may be related to an increase of vascular permeability that occurs during implantation and decidualization. The results also suggest that during decidualization, besides their angiogenic functions, VEGF and its receptors may be involved in other cell processes such as decidual cell differentiation, proliferation and/or cell survival.

Key Words: VEGF; VEGFR-1; VEGFR-2; Immunohistochemistry; Endometrium; Decidua; Angiogenesis; Embryo implantation. 


\section{INTRODUÇÃO}

A implantação embrionária em mamíferos consiste de uma seqüência de eventos que se inicia com a adesão do blastocisto ao epitélio uterino. Este processo é acompanhado de uma série de modificações morfológicas, hormonais e bioquímicas que ocorre entre dois organismos geneticamente diferentes (Weitlauf, 1994).

Em roedores, um dos primeiros sinais da implantação embrionária é caracterizado por um edema generalizado, e pelo aumento da permeabilidade vascular dos vasos sangüíneos situados no estroma uterino subjacente à câmara de implantação onde se aloja o blastocisto (Psychoyos, 1961).

Outro evento que acompanha a implantação embrionária em roedores é a extensa remodelação dos tecidos maternos, conhecido como reação decidual ou decidualização (Abrahamsohn, et al., 2002).

Durante a decidualização em roedores, o endométrio forma dois compartimentos morfologicamente distintos: o tecido decidual anti-mesometrial, ou decídua antimesometrial, local onde se inicia o processo de implantação do embrião; e o tecido decidual mesometrial, ou decídua mesometrial, local de intensa angiogênese, e onde o trofoblasto invade. Nesta região, posteriormente se formará a porção materna da placenta, permanecendo até o final da gestação (Welshand Enders, 1991b; Gu, et al., 1992; Christofferson, et al., 1994, Tan, et al., 1999).

Dentre as diversas respostas uterinas à implantação do blastocisto e á decidualização do endométrio destaca-se o aumento da permeabilidade vascular (Finn, 1977; Parr \& Parr, 1989; Abrahamsohn \& Zorn, 1993). Tanto o aumento da permeabilidade vascular quanto a angiogênese são eventos cruciais para o sucesso da implantação embrionária e da placentação (Ma, et al., 2001). No entanto, os mecanismos moleculares pelos quais o aumento da permeabilidade vascular e a angiogênese que ocorrem no útero ao longo das diferentes etapas da reprodução e durante o processo de decidualização são ainda pouco compreendidos. 
O fator de crescimento endotelial (VEGF) é um potente mitogênico para as células endoteliais e um potente indutor de angiogênese para células endoteliais derivadas de artérias, veias e vasos linfáticos (Ferrara e Davis-Smith, 1997 Dvorak, et al., 1999). O VEGF, também é referido como VEGF-A ou VPF (Fator de Permeabilidade Vascular), pertence a uma família de genes que incluem também o fator de crescimento placentário (PlGF) (Nagy, et al., 2003), VEGF-B (Olofsson, et al., 1996), VEGF-C e o VEGF-D. Estes dois últimos representantes, $\mathrm{C}$ e $\mathrm{D}$ estão associados à regulação do processo de angiogênese nos vasos linfáticos (Nagy, et al., 2003).

O VEGF exerce sua função via dois receptores da família da tirosina quinase, o cfms-like tirosina kinase (Flt-1: VEGFR-1) (Shibuya, et al., 1990) e o fetal liver kinase (Flk1 ou KDR em humanos:VEGFR-2) (Millauer, et al., 1993), os quais são expressos pelas células endoteliais. Recentes estudos imunohistoquímicos têm mostrado que além das células endoteliais, os receptores Flk-1 e Flt-1 estão também localizados no epitélio glandular, e no estroma endometrial humano (Meduri, et al., 2000). O VEGF também interage com uma família de co-receptores, as neuroporinas, NP1 e NP2 aumentando a a

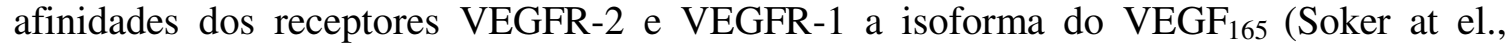
1998; Ferrara, 2004).

A expressão de VEGF e seus receptores tem sido demonstrada durante o ciclo sexual em humanos e em ratos, e nos estágios iniciais da gestação em camundongos (Charnock-Jones, et al., 1993; Shweiki, et al., 1993; Chakraborty, et al., 1995; Wang, et al., 2003). Estudos realizados durante a gestação em ratas mostrou que a expressão de VEGF é regulada pelos níveis de estrógeno e progesterona peri-implantacionais (Shweiki, et al., 1993).

Apesar de vários estudos sobre VEGF e seu papel na formação de novos vasos sangüíneos, e no aumento da permeabilidade vascular terem sido publicados, pouco ainda se sabe onde este fator é expresso exatamente no útero gravídico, especialmente durante o processo de decidualização em camundongos. 


\section{CONCLUSÃO}

No presente estudo ficou demonstrado que o endométrio de camundongos expressam o VEGF e os receptores VEGF-R1 e VEGF-R2 durante o processo de transformação decidual. Esta conclusão principal foi baseada nas seguintes observações:

1. O VEGF foi expresso de maneira espacial e temporal nas células do estroma uterino localizado em torno do embrião, nas células do epitélio luminal e glandular entre o $4^{\circ}$ e o $8^{\circ}$ dias de gestação.

2. A expressão de VEGF, VEGF-R1 e VEGF-R2 no endométrio no $4^{\circ}$. dia de gestação, período em que antecede á implantação do blastocisto, foi mais expressiva no epitélio luminal e glandular do que nas células do estroma sub-epitelial.

3. No 5o. dia de gestação, em resposta à implantação do blastocisto na parede uterina, ocorreu um aumento da expressão de VEGF, VEGF-R1 e VEGF-R2 tanto no epitélio luminla e glandular quanto no estroma mesometrial e na recém estabelecida decídua antimesometrial.

4. A análise imunohistoquímica mostrou que células deciduais maduras e células prédeciduais mesometriais expressam intensamente o VEGF entre o $6^{\circ}$ e o $8^{\circ}$ dias de gestação. Na decídua antimesometrial, a expressão do VEGF foi semelhante aquela da decídua mesometrial, exceto pela diminuição da marcação nas células da decídua madura.

5. Do $5^{\circ}$ ao $8^{\circ}$. dias de gestação, o receptor VEGF-R1 mostrou uma marcação uniforme por toda a decídua mesometrial e antimesometrial. O receptor VEGF-R1 foi altamente expresso pelas células endoteliais dos capilares sinusóides mesometriais.

6. A expressão de VEGF-R2 endométrio decidualizado mostrou o mesmo padrão de marcação semelhante ao do VEGF-R1, exceto pela diminuição de marcação nas células da decídua madura. Assim como o receptor VEGF-R1, o receptor VEGF-R2 foi intensamente expresso pelas células endoteliais dos capilares sinusóides mesometriais. 
7. Em contraste com a marcação no endométrio decidualizado, a marcação para VEGF, VEGF-R1 e VEGF-R2 foi negativa no estroma endometrial dos sítios de inter-implantação no $7^{\circ}$ e $8^{\circ}$. de gestação.

8. No $7^{\circ}$ e $8^{\circ}$. dias de gestação, a marcação para o VEGF, VEGF-R1 e VEGF-R1 foi intensa nas células Nk uterinas.

9. VEGF, VEGF-R1 e VEGF-R2 foram diferencialmente expressos pelas células trofoblásticas gigantes e pelas células do cone ectoplacentário.

Em resumo, a expressão diferencial do VEGF e dos receptores VEGF-R1 e VEGFR2 na decídua mesometrial e antimesometrial e a ausência de marcação no estroma não decidualizado, nos sítios de inter-implantação demonstrou claramente que o VEGF, VEGF-R1 e VEGF-R2 são supra-regulados durante o processo de transformação decidual. 


\section{REFERÊNCIAS BIBLIOGRÁFICAS}

Abrahamsohn PA, Zorn TM, Oliveira SF. Decidua in rodents. In: Glasser, S.R.; Aplin, J.D.;

Giudice, L.C.; Tabibzadeh, S.; editors. The Endometrium. London: Taylor \& Francis

Group. 2002; p. 279-293.

Abrahamsohn PA, Zorn TMT. Implantation and decidualization in rodents. J. Exp. Zool. 1993; 266(6): 603-628.

Abrahamsohn PA. Morphology of the decidua. In: Yoshinaga K, editor. Blastocyst Implantation. Boston: Adams Publishing Group. 1989; p 127-133.

Abrahamsohn PA. Ultrasctrutural study of the mouse antimesometrial decidua. Anat. EmbryoI. 1983; 166(2): 263-274.

Abufalia O, Sherer DM. Transcatheter uterine artery embolization for the management of symptomatic uterine leiomyomas. Obstet. Gynecol. Surv. 1999; 54(12): 745-753.

Alberto-Rincon MC, Zorn TMT, Abrahamsohn PA. Diameter increase of collagen fibrils of the mouse endometrium during decidualization. Am. J. Anat. 1989; 186(4): 417-429.

Amano H, Hayashi I, Endo H, Kitasato H, Yamashima S, Maruyama T, Kobayashi M, Satoh K, Narita M, Sugimoto Y, Murata T, Yoshimura H, Narumiya S, Majima M. Host prostaglandin E(2)-EP3 signaling regulates tumor-associated angiogenesis and tumor growth. J. Exp. Med. 2003; 197(2): 221-232.

Andrade CGT, Abrahamsohn PA, Gondinho F, Samuel E, Zorn TMT. Death and replacement of uterine epithelial cells during oil-induced deciduoma development in the mouse. Anat. Record. 1996; 244(3): 316-326. 
Ashikar AA, Di Santo JP, Croy BA. Interferon gamma contributes to initiation of uterine vascular modification, decidual integrity, and uterine natural killer cell maturation during normal murine pregnancy. J.Exp. Med. 2000; 192(2): 259-270.

Bany BM, Zhang X, Kennedy TG. Effects of epidermal growth factor and interleukin-1 alpha on plasminogen activator secretion and decidualization in rat endometrial stromal cells. Biol. Reprod. 1998; 59(1):131-135.

Bany BM, Kennedy TG. Interleukin-1 alpha regulates prostaglandin production and cyclooxygenase activity in sensitized rat endometrial stromal cells in vitro. Biol. Reprod. 1995; 53(1): 126-132.

Barakai U, Prigent-Tessier A, Tessier C, Gibori GB, Gibori G. Involvement of SOCS-1, the suppressor of cytokine signaling, in the prevention of prolactin-responsive gene expression in decidual cells. Mol. Endocrinol. 2000; 14(4): 554-563.

Baumwell S, Karumachi SA. Pre-eclampsia: clinical manifestations molecular mechanisms. Nephron. Clin. Pract. 2007; 106(2): c72-81 Epub 2007.

Becker CM, D`Amato RJ. Angiogenesis and antiangiogenic therapy in endometriosis. Microvasc. Res. 2008; 74(2-3): 121-130. Epub 2007.

Bell SC. Immunochemical identity of "decidualization-associated protein" and alpha 2 acute-phase macroglobulin in the pregnant rate. J. Reprod. Immunol. 1979; 1(3): 193-206.

Bevilacqua EM, Abrahamsohn PA. Trophoblast invasion during implantation of the mouse embryo. Arch. Biol. Med. Exp. 198; 22(2): 107-118. 
Breier G, Albrecht U, Sterrer S, Risau W. Expression of vascular endothelial growth factor during embryonic angiogenesis and endothelial cell differentiation. Development 1992; 114(2): 521-532.

Brock TA, Dvorak HF, Senger DR. Tumor-secreted vascular permeability factor increases cytosolic $\mathrm{Ca} 2+$ and von Willebrand factor release in human endothelial cells. Am J Pathol. 1991; 138(1): 213-221.

Brown LF, Berse B, Jackman RW, Tognazzi K, Guidi AJ, Dvorak HF, Senger DR, Connolly JL, Schnitt SJ. Expression of vascular permeability factor (vascular endothelial growth factor) and is receptor in breast cancer. Hum. Pathol. 1995; 26(1): 86-91.

Brunet A, Bonni A, Zigmond MJ, Lin MZ, Juo P, Hu LS, Anderson MJ, Arden KC, Blenis J, Greenberg ME. Akt promotes cell survival by phosphorylating and inhibiting a Forkhead transcription factor. Cell. 1999; 96(6): 857-868.

Candeloro L, Zorn TM. Granulated and non-granulated decidual prolactin-related proteinpositive decidual cells in the pregnant mouse endometrium. J. Reprod. Immunol. 2007; 57(2): 122-132.

Cardone MH, Roy N, Stennicke HR, Salvesen GS, Franke TF, Stanbridge E, Frisch S, Reed JC. Regulation of cell death protease caspase-9 by phosphorylation. Science. 1998; 282(5392): 1318-1321.

Carmeliet P, Ferreira V, Breier G, Pollefeyt S, Kieckens L, Gertsenstein M, Fahrig M, Vandenhoeck A, Harpal K, Eberhardt C, Pawling J, Moons L, Collen D, Risau W, Nagy A. Abnormal blood vessel development and lethality in embryos lacking a single VEGF allele. Nature. 1996; 380: 435-439. 
Chakraborty I, Das SK, Dey SK. Differential expression of vascular endothelial growth factor and its receptor rnRNAs in the mouse uterus around the time of implantation. J. EndocrinoI. 1995; 147(2): 339-352.

Charnock-Jones DS, Sharkey AM, Rajput-Williams I, Burch D, Schofield JP, Fountain SA, Boocock CA, Smith SK. Identification and localization of alternately spliced rnRNAs for vascular endothelial growth factor in human uterus and estrogen regulation in endometrial carcinoma cell lines. Biol. Reprod. 1993; 48(5): 1120-1128.

Christofferson RH. Inhibition of angiogenesis. New ways of treatment for arteriosclerosis, cancer and rheumatoid arthritis. Lakartidningen. 1993; 90(3): 133-134.

Christofferson RH, Nilsson BO. Morphology of the endometrial microvasculature during early placentation in the rat. Cell Tissue Res. 1988; 253(1): 209-220.

Claffey KP, Wilkinson WO, Spiegelman BM. Vascular endothelial growth factor. Regulation by cell differentiation and activated second messenger pathways. J. Biol. Chem. 1992; 267(23): 16317-16322.

Compernolle V, Brusselmans K, Acker T, Hoet P, Tjwa M, Beck H, Plaisance S, Dor Y, Keshet E, Lupu F, Nemery B, Dewerchin M, Van Veldhoven P, Plate K, Moons L, Collen D, Carmeliet P. Loss of HIF-2alpha and inhibition of VEGF impair fetal lung maturation, whereas treatment with VEGF prevents fatal respiratory distress in premature mice. Nat. Med. 2002; 8(7): 702-710. Epub 2002.

Connolly DT, Olander JV, Heuvelman D, Nelson R, Monsell R, Siegel N, Haymore BL, Leimgruber R, Feder J. Human vascular permeability factor. Isolation from U937 cells. J. Biol. Chem. 1989; 264(3): 20017-20024.

De Feo VJ. Decidualization. In: Wynn RM, editor. Cellular Biology of the uterus. Amsterdam: North Holland. 1967; p.192-291. 
Dunk C, Ahmed A. Vascular endothelial growth factor receptor-2-mediated mitogenesis is negatively regulated by vascular endothelial growth factor receptor-1 in tumor epithelial cells. Am. J. Pathol. 2001; 158(1): 265-273.

Dvorak HF. Tumors: wounds that do not heal. Similarities between tumor stroma generation and wound healing. N. Engl. J. Med. 1986; 315(26): 1650-1659.

Favard C, Moukadiri H, Dorey C, Praloran V, Plouet J. Purification and biological properties of vasculotropin, a new angiogenic cytokine. Biol. Cell. 1991; 73(1): 1-6.

Ferrara N. Vascular endothelial growth factor: basic science and clinical progress. Endocr. Rev.2004; 25(4): 581-611.

Ferrara N. Role of vascular endothelial growth factor in physiologic and pathologic angiogenesis: therapeutic implications. Semin. Oncol. 2002; 29(6 SuppI16): 10-14.

Ferrara N. Vascular endothelial growth factor and the regulation of angiogenesis. Recent. Prog. Horm. Res. 2000; 55:15-35.

Ferrara N, Davis-Smyth T. The biology of vascular endothelial growth factor. Endocr. Rev. 1997; 18(1): 4-25.

Ferrara N, Carver-Moore K, Chen H, Dowd M, Lu L, O`Shea KS, Powell-Braxton L, Hillan KJ, Moore MW. Heterozygous embryonic lethality induced by targeted inactivation of the VEGF gene. Nature. 1996; 380(6573): 439-442.

Ferrara N, Henzel WJ. Pituitary follicular cells secrete novel heparin-binding growth factor specific for vascular endothelial cells. Biochem. Biophys. Res. Commun. 1989; 161(2): 851-858. 
Finn CA, Pope MD. Infiltration of neutrophil polymorphonuclear leucocytes into the endometrial stroma at the time of implantation of ova and the initiation of the oil decidual cell reaction in mice. J Reprod Fertil. 1991; 91(1): 365-359.

Finn CA, McLaren A. A study of the early stages of implantation in mice. J. Reprod. Fertil. 1967; 13(2): 259-267.

Finn CA, Keen PM. The Induction of deciduomata in the rat. J. Embryol. Exp. Morphol. 1963; 11: 673-682.

Flamme I, Frolich T, Risau W. Molecular mechanisms of vasculogenesis and embryonic angiogenesis. J. Cell Physiol. 1997; 173(2): 206-210.

Folkman J, Klagsbrun M. Angiogenic factors. Science. 1987; 235(4787): 442-447.

Fong GH, Rossant J, Gertsenstein M, Breitman ML. Role of the Flt-1 receptor tyrosine kinase in regulating the assembly of vascular endothelium. Nature. 1995; 376(6535): 66-70.

Fukumura D, Gohongi T, Kadambi A, Izumi Y, Ang J, Yun CO, Buerk DG, Huang PL, Jain RK. Predominant role endothelial nitric oxide synthase in vascular endothelial growth factor-induced angiogenesis and vascular permeability. Proc. Natl. Acad. Sci. USA. 2001; 98(5): 2604-2609.

Gospodarowicz D, Lau K. Pituitary follicular cells secrete both vascular endothelial growth factor and follistatin. Biochem. Biophys. Res. Commun. 1989; 165(1): 292-298.

Grugel S, Finkenzeller G, Weindel K, Barleon B, Mame D. Both v-Ha-Ras and v-Raf stimulate expression of the vascular endothelial growth factor in NIH 3 T3 cells. J. Biol. Chem. 1995; 270(43): 25915-25919. 
$\mathrm{Gu}$ Y, Gibori G. Isolation, culture, and characterization of the two cell subpopulations forming the rat decidua: differential gene expression for activin, follistatin, and decidual prolactin-related protein. Endocrinology. 1995; 136(6): 2451-2458.

Gu Y, Srivastava RK, Ou J, Krett NL, Mayo KE, Gibori G. Cell-specific expression of activin and its two binding proteins in the rat decidua: role of alpha 2-macroglobulin and follistatin. Endocrinology. 1995; 136(9): 3815-3822.

Gu Y, Jayatilak PG, Parmer TG, Gauldie J, Fey GH, Gibori G. Alpha2-Macroglobulin expression in the mesometrial deciduas and its regulation by decidual luteotropin and prolactin. Endocrinology. 1992; 131(3): 1321-1328.

Gurdon JB, Bourillot PY. Morphogen gradient interpretation. Nature. 2001; 413(6858): 797-803.

Halder JB, Zhao X, Soker S, Paria BC, Klagsbrun M, Das SK, Dey SK. Differential expression of VEGF isoforms and VEGF(164)-specific receptor neuropilin-1 in the mouse uterus suggests a role for VEGF(164) in vascular permeability and angiogenesis during implantation. Genesis. 2000; 26(3): 213-224.

Hattori K, Heissig B, Wu Y, Dias S, Tejada R, Ferris B, Hicklin DJ, Zhu Z, Bohlen P, Witte L, Hendrikx J, Hackett NR, Crystal RG, Moore MA, Werb Z, Lyden D, Rafii S. Placental growth factor reconstitutes hematopoiesis by recruiting VEGFVEGF-R1(+) stem cells from bone-marrow microenvironment. Nat Med. 2002; 8(8): 841-849.

He H, Mccartney DJ, Wei Q, Esadeg S, Zhang J, Foster RA, Hayes MA, Tayade C, Van Leuven F, Croy BA. Characterization of a murine alpha 2 macroglobulin gene expressed in reproductive and cardiovascular tissue. Biol. Reprod. 2005; 72(2): 266-275. Epub 2004. 
Holmes K, Roberts OL, Thomas AM, Cross MJ. Vascular endothelial growth factor receptor-2: structure, function, intracellular signalling and therapeutic inhibition. Cell Signal.2007; 19(10): 2003-2012. Epub 2007.

Houck KA, Ferrara N, Winer J, Cachianes G, Li B, Leung DW. The vascular endothelial growth factor family: identification of a fourth molecular species and characterization of alternative splicing og RNA. Mol. Endocrinol. 1991; 5(12): 1806-1814.

Hoy H, Bhardwaj S, Yla-Herttuala S. Biology of vascular endothelial growth factors. FEBS Lett. 2006; 580(12): 2879-2887. Epub 2006.

Jakeman LB, Armanin, M, Phillips HS, Ferrara N. Developmental expression of binding sites and messenger ribonucleic acid for vascular endothelial growth factor suggests a role for this protein in vasculogenesis and angiogenesis. Endocrinology. 1993; 133(2): 848-859.

Jakeman LB, Winer J, Bennett GL, Altar CA, Ferrara N. Binding sites for vascular endothelial growth factor are localized on endothelial cells in adult rat tissues. J Clin Invest. 1992; 89(1): 244-253.

Jayatilak PG, Puryear TK, Herz Z, Fazlebas A, Gibori G. - Expression of rnRNAs and synthesis of proteins by rat antimesometrial and mesometrial decidua. 10: Yoshinaga K, editor. Blastocyst Implantation. Boston: Adams Publishing Group. 1989; p 145-150.

Kaipainanen A, Kaipainen A, Korhonem J, Mustonen T, Van Hinsbergh VW, Fang GH, Dumont D, Breitman M, Alitalo K. Expression of the fms-like tyrosine kinase 4 gene becomes restricted to lymphatic endothelium during development. Proc. Natl. Acad. Sci. USA. 1995; 92(8): 3566-3570.

Kanellis J, Fraser S, Katerelos M, Power DA. Vascular endothelial growth factor is a survival factor for renal tubular epithelial cells. Am. J. Physiol. Renal Physiol. 2000; 278(6): F905-915. 
Katz S, Abrahamsohn PA. lnvolution of the antimesometrial decidua in the mouse. An ultrastructural study. Anat. EmbryoI. 1987; 176(2): 251-258.

Keck PJ, Hauser SD, Krivi G, Sanzo K, Warren T, Feder J, Connolly DT. Vascular permeability factor, an endothelial cell mitogen related to PDGF. Science. 1989; 246(4935): 1309-1312.

Kendall RL, Wang G, Thomas KA. Identification of a natural soluble form of the vascular endothelial growth factor receptor, FLT-1, and its heterodimerization with KDR. Biochem Biophys Res Commun. 1996; 226(2): 324-328.

Kennedy TG, Ross HE. Effect of prostaglandin E2 on rate of decidualization in rats. Prostaglandins. 1993; 46(3): 243-250.

Kennedy TG, Squires PM, Yee GM. Mediators involved in decidualization. ln: Yoshinaga K, editor. Blastocyst Implantation. Boston: Adams Publishing Group. 1989; p. 135-143.

Kennedy TG. Intrauterine infusion of prostaglandins and decidualization in rats with uteri differentially sensitized for the decidual cell reaction. Biol. Reprod. 1986; 34(2): 327-335.

Kleinfeld RG, O'shea JD. Spatial and temporal pattems of deoxyribonucleic acid synthesis and mitosis in the endometrial stroma during decidualization in the pseudopregnant rat. Biol. Reprod. 1983; 28(3): 691-702.

Krehbiel RH. Cytological studies of the decidual reaction in the rat during early pregnancy and in the production of deciduomata. Physiol. ZooI. 1937; 10: 212-238.

Ku DD, Zaleshi JK, Liu S, Brock TA. Vascular endothelial growth factor induces EDRFdependent relaxation in coronary arteries. Am. J. Physiol. 1993; 265(2 Pt 2): H 586-592. 
Lejeune B, Van Hoeck J, Leroy F. Transmitter role of the luminal uterine epithelium in the induction of decidualization in rats. J. Reprod. Fertil. 1981; 61(1): 235-240.

Leung DW, Cachianes G, Kuang WJ, Goeddel DV, Ferrara N. Vascular endothelial growth factor is a secreted angiogenic mitogen. Science. 1989; 246 (4935): 1306-1309.

Levine RJ, Maynard SE, Qian C, Lim KH, England LJ, Yu KF, Schisterman EF, Thadhani R, Sachs BP, Epstein FH, Sibai BM, Sukhatme VP, Karumanchi SA. Circulating angiogenic factors and the risk of preeclampsia. N Engl J Med. 2004; 350(7): 672-683.

Li XF, Charnock-Jones DS, Zhang E, Hiby S, Malik S, Day K, Licence D, Bowen JM, Garden L, King A, Loke YW, Smith SK. Angiogenic growth factor messenger ribonucleic acids in uterine natural killer cells. J. Clin. Endocrinol. Metab. 2001; 86(4): 1823-1834.

Liu Y, Cox SR, Morita T, Kourembanas S. Hipoxia regulates vascular endothelial growth factor gene expression in endothelial cells. Identification of 5'enhancer. Circ. Res. 1995; 77(3): 638-643.

Loeb L. The experimental production of the maternal placenta and formation of the corpus luteum. J. AM. Med. Assoc. 1908; 50: 1897-1901.

Lundkvist O, Ljungkvist I. Morphology of the rat endometrial stroma at the appearance of the pontamine blue reaction during implantation after an experimental delay. Cell Tissue Res. 1977; 184(4): 453-466.

Ma W, Tan J, Matsumoto H, Robert B, Abrahamsohn DR, Das SK, Dey SK. Adult tissue angiogenesis: evidence for negative regulation by estrogen in the uterus. MoI. Endocrinol. 2001; 15(11): 1983-1992.

Maynard SE, Min JY, Merchan J, Lim KH, Li J, Mondal S, Libermann TA, Morgan JP, Sellke FW, Stillman IE, Epstein FH, Sukhatme VP, Karumanchi SA. Excess placental 
soluble fms-like tyrosine kinase 1 (sFlt1) may contribute to endothelial dysfunction, hypertension, and proteinuria in preeclampsia. J Clin Invest. 2003; 111(5): 649-658.

Melder RJ, Koenig GC, Witwer BP, Safabakhsh N, Munn LL, Jain RK. During angiogenesis, vascular endothelial growth factor and basic fibroblast growth factor regulate natural killer cell adhesion to tumor endothelium. Nat. Med. 1996; 2(9): 992-997.

Millauer B, Wizigmann-Voos S, Schnurch H, Martinez R, Moller NP, Risau W, Ullrich A. High affinity VEGF binding and developmental expression suggest Flk-1 as a major regulator of vasculogenesis and angiogenesis. CeIl. 1993; 72(6):835-846.

Mossman HW. Comparative morphogenesis of the fetal membranes and accessory uterine structures. Contributions to Embryology. 1937; 25: 133-426.

Mossman HW. Vertebrate retal membranes. Rutgers University Press, New Brunswick, 1987; p.383.

Mueller MM, Fusenig NE. Tumor-stroma interactions directing phenotype and progression of epithelial skin tumor cells. Differentiation. 2002; 70(9-10): 486-497.

Nagy JA, Dyorak AM, Dyorak HF. VEGF-A (164/165) and PIGF: roles in angiogenesis and arteriogenesis. Trends Cardiovasc Med. 2003; 13(5): 169- 175.

Namiki A, Brogi E, Kearney M, Kim EA, Wu T, Couffinhal T, Varticovski L, Isner JM. Hypoxia induces vascular endothelial growth factor in cultured human endothelial cells. J. Biol. Chem. 1995; 270(52): 31189-31195.

Öberg-Welsh C, Sandler S, Andersson A, Welsh M. Effects of vascular endothelial growth factor on pancreatic duct cell replication and the insulin production of fetal islet-like cell clusters in vitro. Mol. Cell Endocrinol. 1997; 126(2): 125-132. 
Okada F, Rak JW, Croix BS, Lieubeau B, Kaya M, Roncari L, Shirasawa S, Sasazuki T, Kerbel RS. Impact of oncogenes in tumor angiogenesis: mutant K-ras up-regulation of vascular endothelial growth factor/vascular permability factor is necessary, but not sufficient for tumorigenicity of human colorectal carcinoma cells. Proc. Natl. Acad. Sci. USA. 1998; 95(7): 3609-3614.

Olofsson BP, Ajusola K, Kaipainen A, Von Euler G, Joukoy V, Saksela O, Orpana A, Pettersson RF, Alitalo K, Eriksson U. Vascular endothelial growth factor B, a novel growth factor for endothelial cells. Proc. Natl. Acad. Sci. USA. 1996; 93(6):2576-2581.

Olsson AK, Dimberg A, Kreuger J, Claesson-Welsh L. VEGF receptor signalling - in control of vascular function. Nat Rev Mol Cell Biol. 2006; 7(5): 359-371.

Orwig KE, Dai G, Rasmussen CA, Soares MJ. Decidual/trophoblast prolactin-related prateio: characterization of gene structure and cell-specific expression. Endocrinology. 1997; 138(6):2491-2500.

O'shea JD, Kleinfeld RG, Morrow HA. Ultrastructure of decidualization in the pseudopregnant rat. Am. J. Anat. 1983; 166(3): 271-298.

Park JE, Keller GA, Ferrara N. The vascular endothelial growth factor (VEGF) isoforms: differential deposition into the subepithelial extracellular matrix and bioactivity of extracellular matrix-bound VEGF. Mol. Biol. Cell. 1993; 4(12): 1317-1326.

Parr MB, Parr ER. The implantation reaction. In: Wynn RM, Jollie WP, editors. Biology of the Uterus. New York: Plennum Publishing Corporation. 1989; p.233-277.

Peel S. Granulated metrial gland cells. Adv. Anat. Embryol. Cell BioI. 1989; 115: 1-112.

Peel S, Bulmer D. The fine structure of the metrial gland in relation to the origin of the granulated cells. J. Anat. 1977; 123(Pt 3): 687-696. 
Phillips HS, Hains J, Leung DW, Ferrara N. Vascular endothelial growth factor is expressed in rat corpus luteum. Endocrinology. 1990; 127(2): 965-967.

Plouet J, Moukadiri HJ. Characterization of the receptor to vasculotropin on bovine adrenal cortex-derived capillary endothelial cells. J Biol Chem. 1990; 265(36): 22071-22074.

Plouet J, Schilling J, Gospodarowicz D. Isolation and characterization of a newly identified endothelial cell mitogen produced by AtT20 cells. EMBO J. 1989; 8(12): 3801-3806.

Psychoyos A. Endocrine control of egg implantation. In: Greep, RO (ed.) Handbook of Physiology, sect. 7, vol 2, part 2. American Physiology Society, Washington DC, 187, 1973.

Psychoyos A. A penneabilité capillarie et decidualisation utérine. C R Aead Sei (Paris). $1961 ; 252: 1515-1517$.

Rasmussen CA, Orwig KE, Velucci S, Soares MJ. Dual expression of prolactin-related protein in decidua and trophoblast tissues during pregnancy in rats. Biol. Reprod. 1997; 56(3): 647-654.

Rasmussen CA, Hashizume K, Orwig KE, Xu L, Soares MJ. Decidual prolactin-related protein: heterologous expression and characterization. Endocrinology. 1996; 137(12): $5558-5566$.

Rogers PA, Murphy CR, Squires KR, Mac Lennan AH. Effects of relaxin on the intrauterine distribution and antimesometrial positioning and orientation of rat blastocysts before implantation. J. Reprod. Fertil. 1983; 68(2): 431-435.

Rogers PA, Murphy CR, Gannon BJ. Changes in the spatial organization of the uterine vasculature during implantation in the rat. J. Reprod. Fertil. 1982; 65(1): 211-214. 
Sakoff JA, Murdoch RN. Uterine receptivity to the artificial deciduogenic agent, concanavalin A, in pseudopregnant QS mice. Reprod. Fertil. Dev. 1995; 7(5): 1095-1100.

Sawano A, Iwai S, Sakurai Y, Ito M, Shitara K, Nakahata T, Shibuya M. Flt-1, vascular endothelial growth factor receptor 1 , is a novel cell surface marker for the lineage of monocyte-macrophages in humans. Blood. 2001; 97(3): 785-971.

Scheufler KM, Drevs J, van Velthoven V, Reusch P, Klisch J, Augustin HG, Zentner J, Marme D. Implications of vascular endothelial growth factor, sFlt-1, and sTie-2 in plasma, serum and cerebrospinal fluid during cerebral ischemia in man. J Cereb Blood Flow Metab. 2003; 23(1): 99-110.

Schwarzenbach H, Chakrabarti G, Paust HJ, Mukhopadhyay AK. Gonadotropin-mediated regulation of the murine VEGF expression in MA-10 Leydig cells. J. Androl. 2004; 25(1): 128-139.

Senger DR, Brown LF, Claffey KP, Dvorak HF. Vascular permeability factor, tumor angiogenesis and stroma generation. Invasion Metastasis. 1994-1995; 14(1-6): 385-394.

Senger DR, Van de Water L, Brown LF, Nagy JA, Yeo KT, Yeo TK, Berse B, Jackman RW, Dvorak AM, Dvorak HF. Vascular permeability factor (VPF, VEGF) in tumor biology. Cancer Metastasis Rev. 1993;12(3-4): 303-324.

Senger DR, Connolly DT, Van De Water L, Feder J, Dvorak HF. Purification and NH2terminal amino acid sequence of guinea pig tumor-secreted vascular permeability factor. Cancer Res. 1990; 50(6): 1774-1778.

Shalaby F, Rossant J, Yamaguchi TP, Gertenstein M, Wu XF, Breitman ML, Schuh AC. Failure of blood island formation and vasculogenesis in flk-1 deficient mice. Nature. 1995; 376(6535): 62-66. 
Shen H, Clauss M, Ryan J, Schmidt AM, Tijburg P, Borden L, Connolly D, Stern D, Kao J. Characterization of vascular permeability factor/vascular endothelial growth factor receptors on mononuclear phagocytes. Blood. 1993; 81(10): 2767-2773.

Shibuya M, Yamaguchi S, Yamane A, Ikeda T, Tojo A, Matsushime H, Sato M. Nucleotide sequence and expression of a novel human receptor-type tyrosine kinase (flt) closely related to the fms family. Oncogene. 1990; 5(4): 519-524.

Shiraishi S, Nakagawa K, Kinukawa N, Nakano H, Sueishi K. Immunohistochemical localization of vascular endothelial growth factor in the human placenta. Placenta. 1996; 17(2-3): 111-121.

Shweiki D, Itin A, Neuefeld G, Gitay-Goren H, Keshet E. Patterns of expression of vascular endothelial growth factor (VEGF) and VEGF receptors in mice suggest a role in hormonally regulated angiogenesis. J. Clin. Invest. 1993; 91(5):2235-2243.

Snell GD. The early embryology of the mouse. In: Snell GD, editor. Biology of the laboratory mouse. New York: Dover Publications Ine. pl-54, 1941.

Soh EY, Sobhi SA, Wong MG, Meng YG, Siperstein AE, Clark OH, Duh QY. Thyroidstimulating hormone promotes the secretion of vascular endothelial growth factor in thyroid cancer cell lines. Surgery. 1996; 120(6): 944-947.

Sondell M, Lundborg G, Kanje M. Vascular endothelial growth factor has neurotrophic activity and stimulates axonal outgrowth, enhancing cell survival and Schwann cell proliferation in the peripheral nervous system. J Neurosci. 1999; 19(14): 5731-5740. 
Sonoshita M, Takaku K, Sasaki N, Sugimoto Y, Ushikubi F, Narumiya S, Osshima M, Taketo MM. Acceleration of intestinal polyposis through prostaglandin receptor EP2 in Apc(Delta 716) knockout mice. Nat. Med. 2001; 7(9): 1048-1051.

Stewart I, Peel S. Granulated metrial gland cells at implantation sites of the pregnant mouse uterus. Anat. Embryol. 1980; 160(2): 227-238.

Stewart I, Peel S. The differentiation of the decidua and the distribution of metrial gland cells in the pregnant mouse uterus. Cell Tissue Res.1978; 187(1): 167-79.

Stewart I, Peel S. The structure and differentiation of granulated metrial gland cells in the pregnant mouse uterus. Cell Tissue. Res.1977; 184(4): 517-527.

Takahashi H, Shibuya M. The vascular endothelial growth factor (VEGF)/VEGF receptor system and its role under physiological and pathological conditions. Clinical Science. 2005; 109(3): 227-241.

Tan J, Paria BC, Dey SK, Das SK. Differential uterine expression of estrogen and progesterone receptors correlates with uterine preparation for implantation and decidualization in the mouse. Endocrinology. 1999; 140(11): 5310-5321.

Tischer E, Mitchell R, Hartman T, Silva M, Gospodarowicz D, Fiddes JC, Abraham JA. The human gene for vascular endothelial growth factor. Multiple protein forms are encoded through alternative exon splicing. J Biol Chem. 1991; 266(18): 11947-11954.

Torry DS, Torry RJ. Angiogenesis and the expression of vascular endothelial growth factor in endometrium and placenta. Am. J. Reprod. Immunol. 1997; 37(1): 21-29.

Vaisman N, Gospodarowicz D, Neufeld G. Characterization of the receptors for vascular endothelial growth factor. J Biol Chem. 1990; 265(32): 19461-19466. 
Vidsiunas AK. Desenvolvimento da decídua mesometrial de camundongos. Estudo morfológico e imunohistoquímico. [Dissertação (Doutorado em Biologia Celular e Tecidual)]. São Paulo (Brasil): Instituto de Ciências Biomédicas, Universidade de São Paulo, 2005.

Wang H, Gordon D, Olszewshi B, Song YL, Kovesdi I, Keisse JA. Rat sponge implant model: a new system for evaluating angiogenic gene transfer. Int. J. Mol. Med. 2000; 6(6): 645-653.

Wang H, Li Q, Lin H, Yu X, Qian D, Dai J, Duan E, Zhu C. Expression of vascular endothelial growth factor and its receptors in the rhesus monkey (Macaca mulatta) endometrium and placenta during early pregnancy. Mol. Reprod. Dev. 2003; 65(2): 123 131.

Weitlauf HM. Biology of implantation. In: Knobil E, Neil JD, Editors. The Physiology of Reproduction. $2^{\text {nd }}$ ed. New York: Raven Press. 1994; p. 391-440.

Weitlauf HM. Biology of implantation. In: Knobil E, Neil JD, Editors. The Physiology of Reproduction. V 01. 1. New York: Raven Press. 1988; p.231-262.

Welsh AO, Enders AC. Chorioallantoic placenta formation in rat: I. Luminal epithelial cell death and extracellular matrix modifications in the mesometrial region of implantation chambers. Am. J. Anat. 1991a; 192(3):215-231.

Welsh AO, Enders AC. Chorioallantoic placenta formation in the rat II: Angiogenesis and maternal blood circulation in the mesometrial region of the implantation chamber prior to placenta formation. Am. J. Anat. 1991b; 192(4): 347-365.

Welsh AO, Enders AC. Light and electron microscopic examination of the mature decidual cells of the rat with emphasis on the antimesometrial decidua and its degeneration. Am. J. Anat. $1985 ; 172(1): 1-29$. 
Wimsatt WA. Some comparative aspects of implantation. Biol. Reprod. 1975; 12(1): 1-40.

Zhang Y, Deng Y, Luther T, Muller M, Ziegler R, Waldherr R, Stem R, Nawroth PP. Tissue factor controls the balance of angiogenic and antiangiogenic properties of tumor cells in mice. J. Clin. Invest. 1994; 94(3): 1320-1327.

Zhao L, Wang K, Ferrara N, Vu TH. Vascular endothelial growth factor co-ordinates proper development of lung epithelium and vasculature. Mech. Develop. 2005; 122(7-8): 877-886.

Zorn TM, Bevilacqua EM, Abrahamsohn PA. Collagen remodeling during decidualization in the mouse. Cell Tissue Res. 1986; 244(2): 443-448.

De acordo com:

International Committe of Medical Journal Editors. Uniform requirements for manuscripts submitted to Biomedical Journal: sample references. Available from: http://www.icmje.org [2004 May 06] 